\title{
Environment of estates and crime prevention through urban environment formation and modification
}

\author{
Kvetoslava MatlovičováA, Peter Mocák ${ }^{B}$, Jana Kolesárovác \\ Received: January 21, 2016 | Revised: May 15, 2016 | Accepted: September 12, 2016
}

\begin{abstract}
Due to the significant impact of criminality on the quality of life in a particular territory, criminality is attracting more and more attention from local authorities which are trying to reduce it. In this respect, the concept of CPTED (Crime Prevention Through Environmental Design) which is quite often used outside of Slovakia and is based on prevention of criminality through the appropriate design of urban environments, seems to be useful. The study offers the characteristics of CPTED principles and also suggests possibilities for its application within inner-city criminality on model territories of the city of Prešov (Slovakia) as an usable way of reducing crime in other mainly East-central European cities.
\end{abstract}

Keywords: CPTED (Crime Prevention through Environmental Design), criminality, criminality perception, quality of life.

\section{Introduction}

In the last decade, social development has been increasingly influenced by economic and cultural globalization as well as European integration, increasing mobility, de-industrialization and the growing importance of the service sector as well as creative and cultural industries (Olsson, Berglund, 2009). The changing paradigm of territorial development leads to a reassessment of the objectives of economic development in line with the new view on those significant elements which characterize the attractiveness of an area and its ability to compete with other areas and environments. The strategy for improving the quality of life of a given city's inhabitants, from the perspective of maintaining its current status while attracting new residents (e.g. Romelić, et al. 2007, Lukić, 2002; Lukić, Jakovčić 2004), is usually an important part of marketing plans for the development of these areas.
Increasing the competitiveness of cities is necessarily based on the creation and continual improvement of living conditions that satisfy the needs of target population groups in a wider range than other territories competing for their business. Ensuring a "high quality of life" can thus be described as a primary goal of public policy. The issue of solving inner-city crimes, including its objective and subjective dimensions, is part of these efforts. This paper will point out how it is possible to use the knowledge of objective and subjective dimensions of inner-city criminality and to apply this knowledge in addressing its prevention through the formation and modification of some elements of the urban environment. Despite the narrow thematic focus of the study, the submitted assessment also takes into account other attributes of the quality of life in the monitored area, which have been analysed in some other works, e.g.: Matlovičová (2011, 2014).

A Department of Geography and Applied Geoinformatics, Faculty of Humanities and Natural Sciences, University of Prešov, 17.novembra 1, 08116 Prešov, Slovakia; kveta.matlovicova@gmail.com

B SEAK Energetics, Levočská 109 Slovakia Prešov, Slovakia; petomocak@gmail.com

C Department of Public Administration, School of Economics and Management of Public Administration in Bratislava, Furdekova 16, 85104 Bratislava 5, Slovakia

* Corresponding author: Kvetoslava Matlovičová, e mail: kveta.matlovicova@gmail.com 


\section{Multidisciplinary approach to reducing crime}

The quality of what a city can offer is an important element in the decision making process of its residents whether to stay in the city or to choose to live somewhere else that can better meet their vision of optimal conditions for life. Based on personal experience or unconscious ideas strongly supported by media images of desolation, fear of crime has become a natural part of the decision-making process in selecting the place of residence. Thus, crime as a negative social phenomenon has become part of our everyday life. It has objective and subjective dimensions, while the subjective dimension is often represented by citizens' fear and concern about their safety and the security of their property (Matlovičová, Mocák, 2014).

Crime is a dreaded phenomenon with a long history and is also one of the oldest and most intensively studied fields across the entire spectrum of scientific disciplines. Each study has enriched the academic debate with their own view and thus has created a sufficiently broad basis for an integrated approach which is based on their interconnection as well as on finding possible mutual intersections. Consequently, this allows us to capture a full range of possible causes of crime.

On this basis, in the second half of the last century, the first attempts to use linked arrangements (or functional clarification of urban space arrangement through the "eyes on the street" concept) appeared and the aesthetics of city physical environment as a possible means for reducing crime (Wood, 1961; Jacobs, 1961; Jeffrey, 1971). Later studies then created a sufficient theoretical basis for shaping an urban concept of CPTED (Crime Prevention Through Environmental Design), which points at the potential for reduction of certain forms of criminality through the elements of environment.

\section{Historical background to the CPTED concept}

The formation of the CPTED concept, as it is known today, has undergone a long development from a historical perspective. During this period, it has been influenced by knowledge coming from different disciplines. This concept also exists as a result of interactions between people and the physical environment. The first attempts, which led to efforts to control and influence the behaviour of people through the use of environment specifics, are as old as ancient culture. The Sumerians (400o BC) were already able to respect each other's property. In the $8^{\text {th }}$ century, the Chinese tried to achieve certain consistency across the space when creating their own cities. Proposals by representatives of the University of Chicago were closer to the current concept from the content perspective. These authors were especially interested in the relationship between urbanization and rising crime (see chapter 3.6.1) (Crowe, Zahm, 1994).

The first serious discussions that laid the foundations of CPTED began to appear in the literature of the 1970s. Elizabeth Wood was the first author who highlighted the importance of the arrangement of the physical environment. In her work Housing Design (1961), she presents her own proposals aimed at improving the quality of life and enhancing the aesthetic quality of the living environment. Following these objectives, she created a broad guideline to improve the security situation in such environments (Robinson, 1996). Another author who directly addressed the issue of crime in the city was the American journalist Jane Jacobs (1975). In her book The Death and Life of American Cities, she criticizes the environment of American cities, especially in Boston. Based on empirical research, she came up with the idea of more diverse land use. She states that there should be a clear border between public and private space as well as clearly identified functions of a given environment. One of the proposals that she presents in this publication is the implementation of the concept of "eyes on the street". This proposal, mainly because of its nature, has become the basis of the first principle of the CPTED concept - natural surveillance - as a tool for reducing opportunities to commit a crime (Keppl, Benkovičová, 2011).

The name of the above mentioned criminologist is related to a significant milestone in the development of the CPTED concept. In 1971, C. Ray Jeffrey used the term "Crime Prevention Through Environmental Design" for the first time. Specifically, he used this term in his book with the same title. In this work, he describes the relationship between urban planning and crime and points out that sociologists significantly overestimate the social causes of crime, e.g. relative deprivation and sub-cultural influences and neglect biological and environmental determinants. He then claims that prevention should have been focused on factors related to the biology of crime. It should have been aimed at reducing opportunities within the environment for crime (Clarke, 2002).

During the same period, O. Newman's work Defensible Space - Crime Prevention Through Urban Design (1972) had a significant impact on the formation of this concept. Newman's work has become the theoretical basis for this concept as we know it today.

\section{CPTED concept and its principles}

According to Newman (1972), a defensible space is created using the residents' control. One of the basic characteristics of defensible space is the fact that residents are responsible for the space and they can protect the 
space on their own. The areas in which such environment is missing, or its real or symbolic boundaries are not set out, are characterized by increased susceptibility to committing a crime (e.g. long dark walkways and estates) (Polišenská, 2010). The basis of Newman' theory is formed by the four basic terms that are used to explain defensible space: image, safe zones, natural surveillance, and territory (Remy, 2000). The greatest attention is paid to the last two terms. According to the potential possibilities of committing crimes, he divides each territory into following sections: public, semi-public, semi-private, and private. Fencible area mainly consists of semi-private and private sections. The stratification of these sections is depicted in Figure 7 (Sorensen, et al., 2008).

As stated by T. Crowe (2000), the purpose of the whole CPTED concept is "the proper design and effective use of the built environment, which can lead to a reduction in the incidence of crime and fear of crime as well as to improvement in the quality of life". The very concept is considered by experts as a specific field of study that focuses on (Sorensen, et al., 2008):

a) the characteristics of the physical environment (e.g. parking area, parks, housing estates, etc.),

b) the behaviour of people in relation to their physical environment,

c) the more efficient use of existing space or its adjustments designed to prevent unwanted behaviour.

According to T. Crowe (2000) the basis of the whole concept is formed by three basic principles or approaches that should be applied in any design of urban element or particular strategy. These approaches are as follows:

1. natural surveillance - visual monitoring of the area and constant watching of potential offenders;

2. natural access control - minimization of access to potential target and creation of barriers for risks perception at offender;

3. territorial reinforcement and maximization of the spatial differentiation clarity - a clear visual differentiation of public and private space (property).

Natural surveillance is a concept focused on trying to keep a potential offender under constant surveillance. Each area should be under such visual inspection which would allow us to see everything that happens in front of or around that space. When implementing any project, attention should be placed on increasing the possibilities of natural visual overview (Schmeidler, 200o). The main advantage of this concept is the maximization of opportunities to prevent the crimes since each of the residents can see the offender earlier than the police. A typical example of increasing the natural visual overview is the proper placement of windows on buildings, street lighting or environment landscaping (Pauls et al., 2000).

The second principle - natural access control - is also focused on reducing the opportunities for committing a crime in a particular territory. The main aim of such reduction is to make limited access axes to the offender's target as well as to evoke a certain feeling of risk perception in offenders, which will discourage them from committing a planned crime (City of Orlando, 2007). This objective can be achieved, for instance, by clear placing of visible entrances to buildings, which are located in areas with limited visibility. One of the options is the use of various natural elements (trees, bushes), which can coordinate the movement of pedestrians and at the same time, prevent vandalism (Henrico Police, 2011).

Territorial reinforcement is the last important principle building the theoretical basis of CPTED. Tools of territoriality involve various design features or symbols (pavement tiles, fences, walls, etc.), which serve to distinguish public from private property. At the same time, these small elements of urban environment deliver to offenders a message that committing a crime in this area is not tolerated (Pauls, et al., 200o). Properly designed territoriality can increase a sense of responsibility for ownership and foster identification with that place. The whole effort in creating an architectural design of the environment should be directed at minimizing locations with hardly identified function and way of use (e.g. areas between blocks, underpasses, etc.) (Schmeidler, 200o).

Henrico Police (2011) claims that besides these three basic strategies, a number of other supporting concepts exist such as:

1. Maintenance - ensuring the continuation of the use of space for intended purpose, defines property rights;

2. Activity Support - supporting activities thanks to which people themselves become the "eyes of the street";

3. Target Hardening - involves the use of mechanical devices (e.g. security systems, alarms, improved lighting) and increases the a place's protection from crime;

4. Unassigned Space - focuses on places that serve no purpose and over which nobody exercises control;

5. Design Conflict - applies if there is a conflict between two irreconcilable activities used in the same space.

6. Context - before applying any specific proposal, context assists in finding results when applying proposals in a specific area;

7. Crime generators - locate places that are at the heart of any potential spread of crime. (Henrico Police (2011) 
In order to respect the above outlined principles, finding optimal urban environment elements arrangement options requires the adoption of (Crow, 2000):

a) mechanical and technical measures, which make it harder for potential offenders to realize their intentions. These include, for instance, entrance control systems, alarms, and other barriers;

b) organizational measures, which are based mainly on public awareness, education and improving relationships between residents;

c) natural measures based on optimization of spatial arrangement of urban elements which may increase the sense of insecurity in potential offenders and cause a fear of detection or capture.

Of course, it is not possible to compose a versatile concept. Application of CPTED provides only a certain range of possible measures which need to be adapted to the local conditions and cultural peculiarities. Therefore, the optimal mix of measures will be always unique, with the emphasis on good visibility, which can be ensured, in addition to natural view, also through constantly improving technical means.

\section{Methodology - possible approaches to CPTED application in practice}

By applying appropriate CPTED measures, vandalism or other manifestations of violence, property or minor crimes can be minimized. The most common measures are as follows (Pauls, et al. 2002; Prince William County, 2011):

\section{Natural Access Control}

- access to the residential complex enabled by a maximum of two entrances;

- the use of balcony railings made of opaque materials;

- clearly defined entrances to residential complexes and adjacent parking areas by landscaping, architectural elements or symbolic gates;

- blocked blind spaces using fences, gates or other elements of landscaping;

- the use of electronic doorman systems.

2. Natural Surveillance

- the possibility to see the front door from the street or the front door should be under the supervision of the residents of the residential complex;

- windows placed on all four sides of the building provide full visibility of the whole area between blocks of flats;

- parking places reserved for residents and visitors help to identify unauthorized parking;

- adequate lighting of parking places and pavements;
- containers for communal waste placed in a way to avoid creating so called blind spots, which increase the possibility of assaults.

3. Territorial Reinforcement

- a clear definition of the border between private and public property;

- hedges or bushes up to one meter high;

- clear signage of all housing units using numbers that are easily observed from the street;

- a mailbox placed next to the appropriate housing complex so it is under the supervision of the public. (Pauls, et al., 2000; Prince William County, 2011)

There are also many other measures aimed at preventing crime in residential areas. Each block of flats has its own specifics requiring individual design and selection of measures that can eliminate problems of crime in a given complex in the most effective way. In general, the most preferred principle is the principle of good and clear visibility of urban elements in these areas.

\section{Crime in the city of Prešov based on statistical surveys}

The main objective of the research is, using the perspective of CPTED, to offer empirical material that can be used in assessing the perception of the quality of life and attractiveness of the city of Prešov for living. Prešov is the third largest city in Slovakia (9100o inhabitants) and the administrative centre of the Prešov self-governing region, which is a boundary region with Poland and Ukraine. The evaluation is based on an objective as well as a subjective picture of crime in the city. The objective dimension is analysed through data published by the Police Force of the Slovak Republic and the Municipal Police in Prešov. The subjective dimension of criminality is studied based on field research conducted in different local urban districts (Matlovičová, 2011).

Both dimensions are depicted using data of a different character, which also imposes certain interpretative limitations. In the case of available hard data (objective dimension), there is a problem related to the estimated difference between real and recorded criminality. The estimated values of latent criminality oscillate at a level which is up to $80 \%$ higher than the recorded data (Holcr in: Dale, 2011). Personal field research is considered as the only solution for their objectification (Michalek, 2008). Another problem is also incomplete or insufficient evidence or constantly changing methodology for recording crimes. Another problem is related to the spatial definition of observational units, in terms of which crimes are monitored 
and reported by Police Force of the Slovak Republic. Such observational units usually do not respect the borders of districts and municipalities.

Statistics recorded in the city of Prešov are divided by the Police Force of the Slovak Republic into two district units (Prešov - south and Prešov - north), which also include other rural municipalities. In terms of crime rate, however, the urban districts are highly dominant, which allows us to neglect the impact of rural settlements and to consider these data as usable in monitoring developmental trends in crime.

Based on available data, the rate of recorded crimes in the city of Prešov has been decreasing since 2006 (KRPZ, 2012). The overall decline during the analysed period was nearly $28.5 \%$, while from a long term perspective property crime has been the most common form of criminality (burglary, motor vehicle theft). The overall trend, compared to 2006, is decreasing. In cases of other types of crime, a relatively balanced rate was recorded during the analysed period. The same tendency was also observed in cases of offences registered in the city, which is within the competence of the Prešov Municipal Police (Figure 1).

Based on more detailed analysis of data available since 2010, the highest rate of offences was recorded in the historical centre of the city - a total of 6,512 offences per km2 and in the urban district Mlynský náhon I. In 2010, 1,528 offences were recorded per km2 (Regional Headquarters of Police Force of the Slovak Republic, Prešov, 2012). In this case, however, road traffic offenses comprise a relatively high proportion since the city centre is well known for many transport constraints. In terms of offences against property, public order or offences in the field of violation of generally binding regulations, the most risky areas are city areas with the highest concentration of population. These involve the following estates: Sekčov, Šváby, Sídlisko II, and Sídlisko III.

\section{Perception of the attractiveness of living in Prešov and criminality}

In terms of client oriented city management, the information gained from perceptual surveys on reflections of the geographical area represent a valuable source of data for their users. Despite the fact that so called Mental Maps of areas represent subjective images of the physical environment, their role in area management is often greater than the objective situation. The specific way people perceive a specific area can influence their behaviour and consequently also stimulate or even eliminate certain criminal activities which definitively affect the prosperity of the area. The perceived level of criminality in different parts of the city is probably one of the aspects that are considered in the decision-making process when choosing a place of residence (of course, only if there is a choice and no restrictions from other, especially economic, factors).

The preferential mental map of Prešov (Figure 2) confirmed the patterns of spatial autocorrelation. This means that the majority of respondents (residents) tend to make a more favourable assessment of their immediate environment if they know it better than other more distant ones (non-resident respondents). As much as $7 \%$ of respondents were not able to assess other areas of the city, while saying: "I have no idea, I do not know other neighbourhoods." The residential area Šidlovec, parts of Dúbrava and Sídlisko III were identified as the best neighbourhoods for housing. In contrast, the Šváby and Sekčov estates are considered the worst addresses for housing. From the point of variation dispersion of received responses, the city

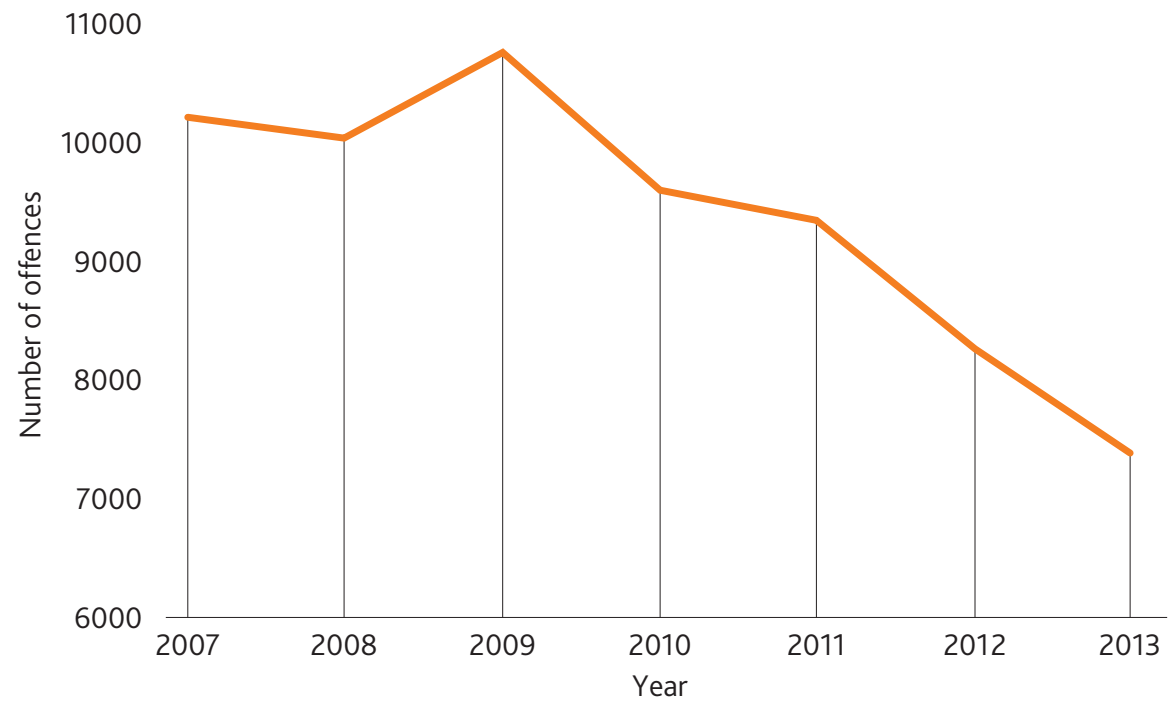

Figure 1. Development of the number of offences detected in Prešov Source: The City Police in Prešov (2007 - 2013) 


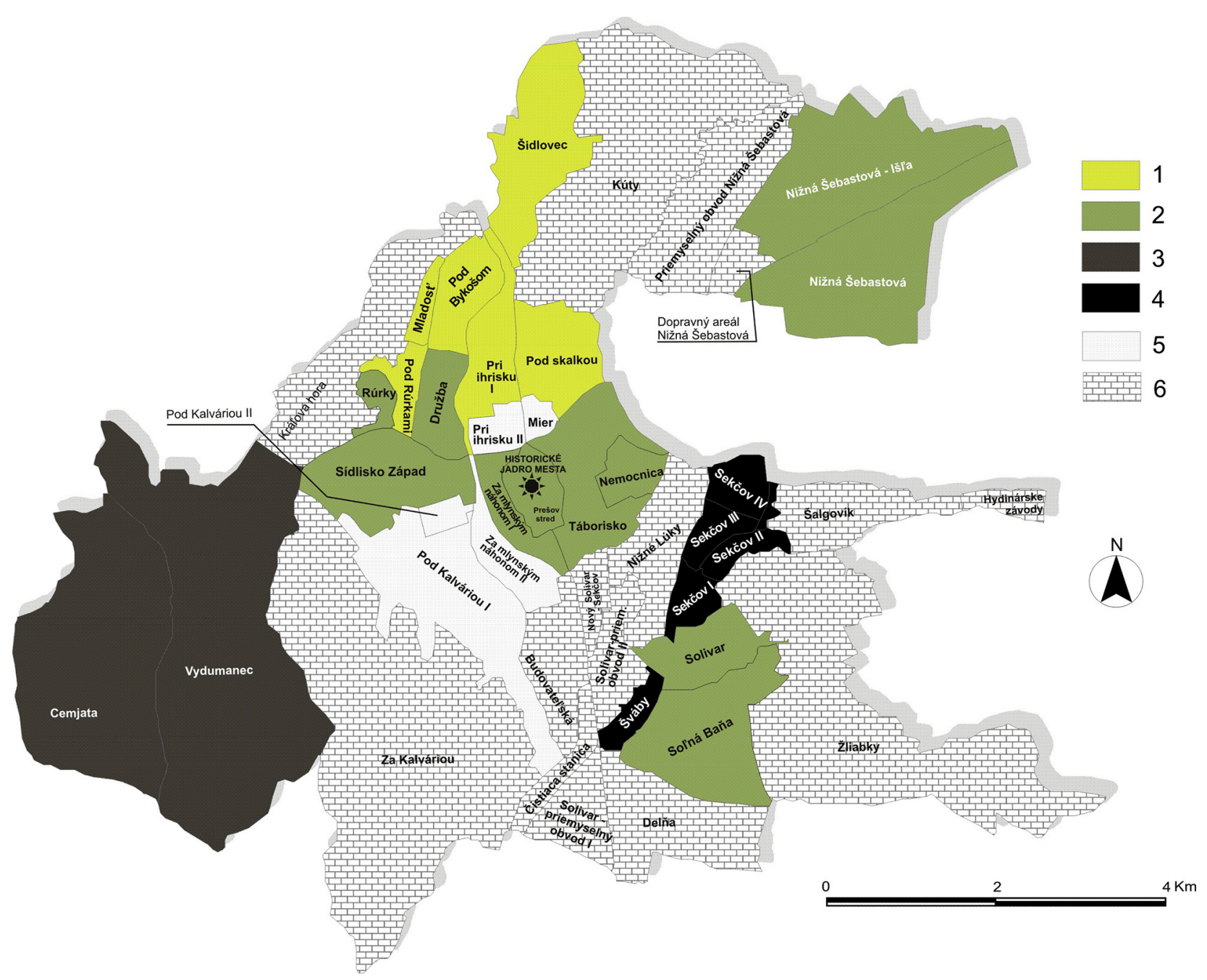

Figure 2. Preferential map in terms of environmental quality perception in Prešov. Legend: 1 - excellent housing, 2 good for housing, 3 - rather bad for housing, 4 - definitely bad for housing, 5 - unclassified area, 6 - the territory with dominant non-resident function Source: Matlovičová (2011)

districts Vydumanec, Cemjata, Dubrava, Šidlovec, and Rúrky were assessed in the most balanced way. The lowest level of agreement among respondents appeared in the evaluation of the Sekčov estate and the city centre (Figure 2) (Matlovičová, 2011).

\section{Application of CPTED in Prešov estates}

Based on the previous brief overviews and two studies carried out in the monitored area (Matlovičová, 2014; 2011), model sites were identified as problematic in terms of the objective and subjective dimensions of criminality. In terms of applying CPTED and urban morphological structures, there are different types of areas: the shopping centre Centrum and the shopping centre Šváby represent a node type within the Šváby and Sídlisko III estates. The Sekčov estate has an aerial character. Model areas were selected according to architecture and urbanism criteria and in all of selected areas, conducted detailed field research was con- ducted aimed at mapping the physical environment from the point of applying the three basic principles of CPTED: natural surveillance, natural access control, and territorial reinforcement.

\section{The Šváby shopping centre}

Based on the research carried out in the city of Prešov, it can be concluded that, in terms of perception of crime rates, those areas performing trade and service functions are perceived very negatively. The highest-risk elements include shopping centres in the largest housing estates located in Prešov, which in terms of structure and overall character share many common elements. They are particularly risky late at night, when the frequency of people's movement around these centres decreases as well as the rate of natural supervision by people in the area. Consequently, they are becoming more attractive locations for committing various criminal activities. This argument is supported by existing statistics recorded by the Munic- 


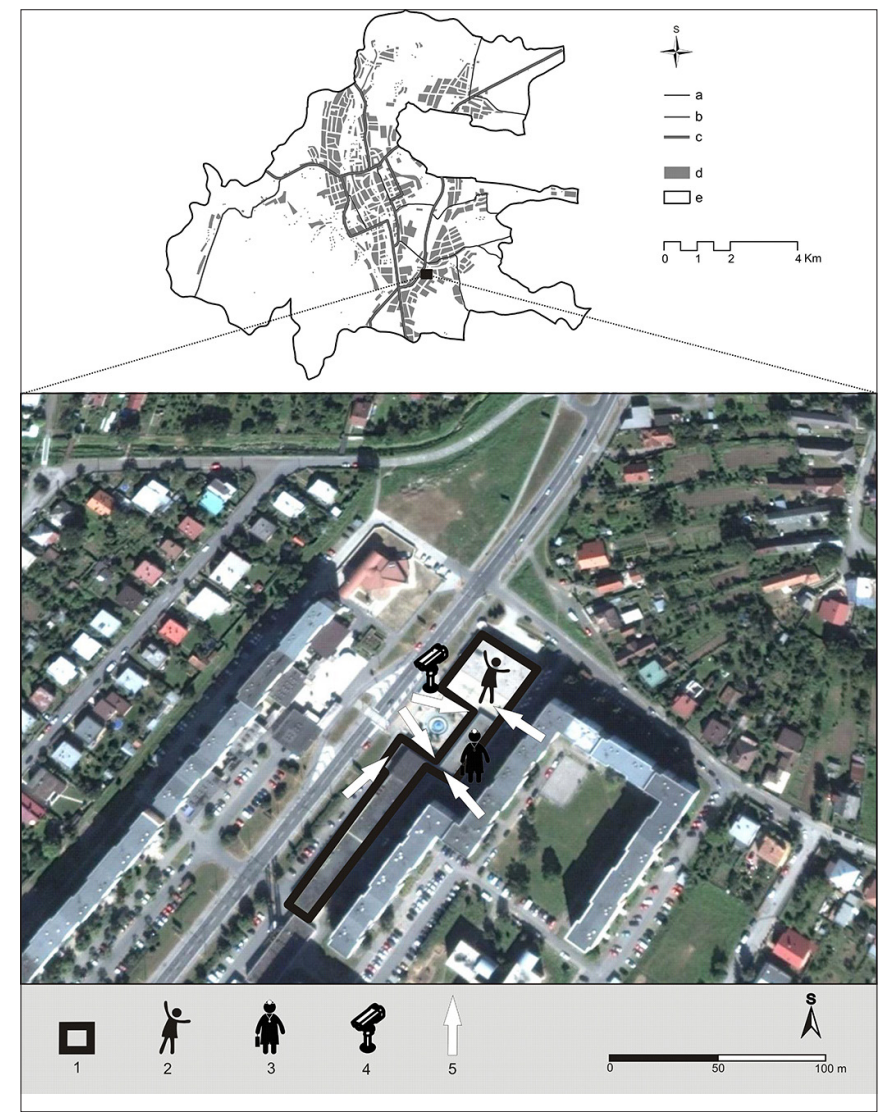

Figure 3. Location of shopping centre Šváby in Prešov. Legend: $\mathrm{a}-3^{\text {rd }}$ class roads, $\mathrm{b}-2^{\text {nd }}$ class roads, $\mathrm{c}-1^{\text {st }}$ class roads, $\mathrm{d}$ - build-up area, e - borders of cadastral area of the city of Prešov; 1 -Šváby shopping centre area, 2 - Cultural Centre, 3 - Health Centre, 4 - city surveillance system, 5 - entrances to the shopping centre.

Source: adapted by VÚZH (2001), the background by Google Map from 2011

ipal Police in Prešov, pursuant to which, vandalism and damage to private or public property occurs most often during the night.

According to our survey as well as surveys conducted previously (e.g. Matlovičová, et al., 2012), the Šváby estate is one of the worst neighbourhoods from the point of view of the environment as well as the degree of security. In its southeast part, the Šváby shopping centre is located. From the morphological point of view, the territory is a compact, set of two-story multipurpose buildings (retail shops, hospitality facilities, services, cultural and health centre with several clinics) with access from an open area - central courtyard. The central courtyard with benches, fountains, and statues serves as a rest area. The first floor is accessible via five entrances. The whole central part of the courtyard underwent renovations in 2009 (Figure 3).

Considering the main principles of CPTED, i.e., natural surveillance, the morphological conception of shopping centre object arrangement in a U-shape provides sufficient fulfilment of the rule "see and be seen". In addition to the natural control from the nearby sev- en-storey apartment buildings, this rule is reinforced by the functional city camera security system. However, the high diversity of the area and the existence of dark corners located mainly behind columns and under staircases are seen as a drawback. Improved surveillance can be achieved, for example, through convex mirrors and adequate lighting at night. Finally, the last proposed measure of improvement could be a new layout and other types of small architectural elements. In the three years since reconstruction, it is evident that the selected type of bench is not appropriate. Replacing them with one of the types depicted in Figure 9 could help, at least partially, regulate their use (e.g. by anti-social people who use them for sleeping or by drunk people for hanging out).

In the field of natural access control, it would be more appropriate to regulate the crossing to one corridor; however, in this case the solution would require the installation of lockable gates to prevent access to the upper floors at night. A concrete solution to vandalism and graffiti could also be the use of green barriers; for example, by planting hedges near walls, 
which enable only restricted access to them or climbing plants (ivy), which naturally cover otherwise unused wall areas. In addition to the protective function, thanks to this rapidly growing green vegetation, which is not difficult to maintain, it would create a more pleasant environment in the summer months.

The last rule is territorial reinforcement and maximization of spatial differentiation clarity, which was not followed up in this case. Given the openness of space and free access to facilities, visual separation of public and private space through the use of raised areas or through at least $1 \mathrm{~m}$ high fencing would be suitable. This will probably not prevent well-planned crimes or intended offences, however, as shown by experiences from abroad (e.g. Schmeidler, 2000; Madliak, et al. 2005; Clinard in Ondrejkovič, 1995), it sends a signal to those offenders who act impulsively: "Hey! This is private property" and crimes committed in this area will not be tolerated. Properly conceived territoriality can cause a sense of responsibility among the general population for ownership as well as identification with that place. All efforts in creating an architectural design for the environment should be directed at minimizing places where it is difficult to identify their function and use (e.g. spaces between blocks of flats, underpasses, etc.) (Schmeidler, 200o).

\section{Sídlisko III}

The shopping centre Centrum can be considered a risky area within the second largest estate in Prešov (Sídlisko III). It is located in its northwest part and represents a complex of nine multipurpose buildings with predominantly commercial and service functions (retail shops, hospitality facilities, health centre, and a library). In the context of the city, the location of a secondary vocational school between these establishments can be considered as a certain peculiarity. The central entrance to the shopping centre is near a bus stop, which creates the impression that the territory is constantly under natural surveillance. The problem is a number of other entrances to the area (Figure 4).

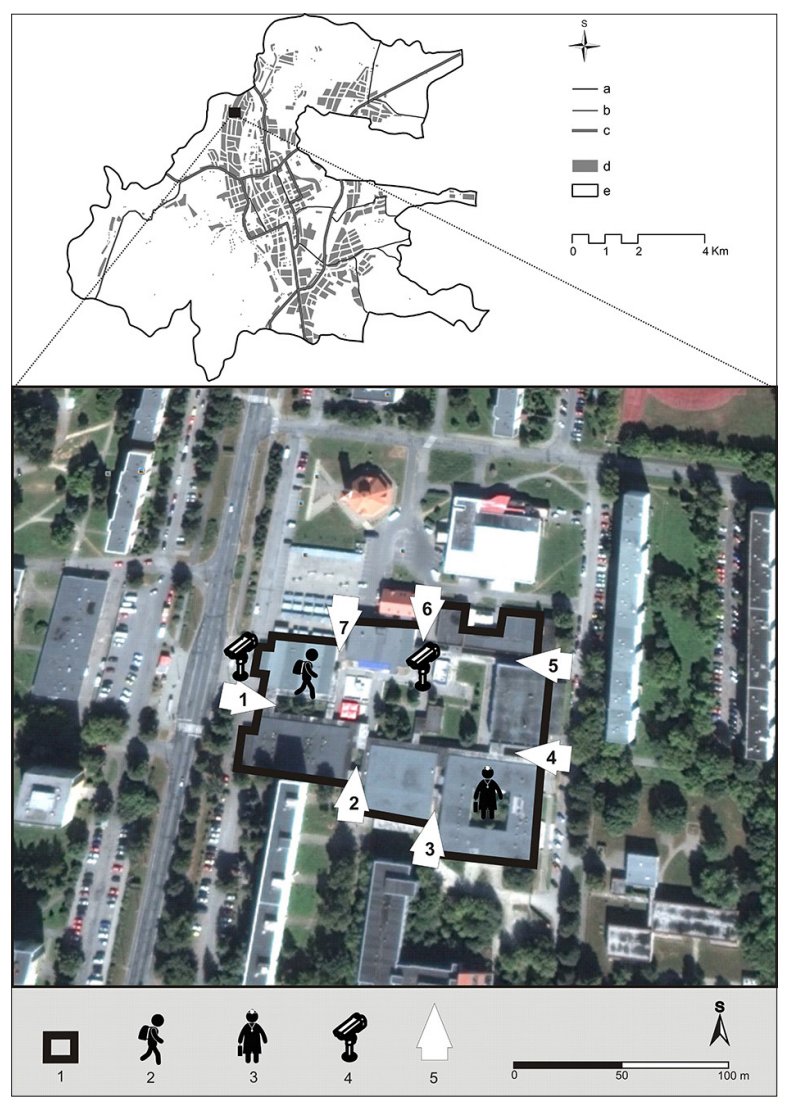

Figure 4. Location of shopping centre Centrum in Prešov. Legend: $a-3^{\text {rd }}$ class roads, $b-2^{\text {nd }}$ class roads, $c-1^{\text {st }}$ class roads, $\mathrm{d}$ - build-up area, e - borders of cadastral area of the city of Prešov; 1 - area of shopping centre Centrum, 2 - School, 3 - Health Centre, 4 - city surveillance system, 5 - entrances to the campus centre. Source: adapted by VÚZH (2001), the background Google Map from 2011 


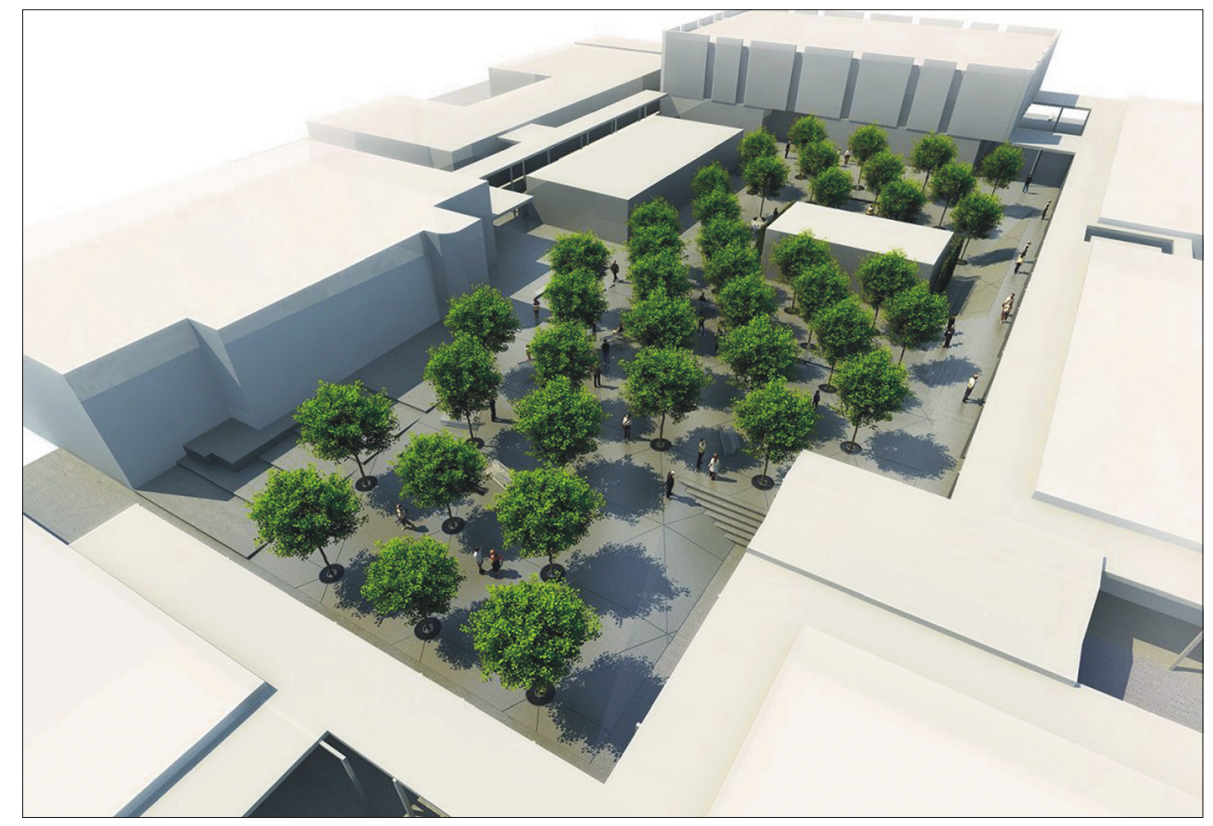

Figure 5. Revitalization project of the shopping centre Centrum in Prešov, designed by ZeroZero $^{\mathrm{TM}}$

Source: Official website of the city of Prešov (2013)

This relatively exposed area had been especially neglected and vandalised for a longer period. That is why the citizens built up pressure on the City Council to commit to a programme of regeneration. In late 2014, the inner area was done up and, in terms of CPTED, some problematic elements were removed. In particular, natural surveillance was increased and potential offenders can be constantly monitored. The original space was extremely derelict, which offered numerous options for hiding from the public eye. Existing niches, nooks or unmaintained green islands attracted vandals and rioters, who disrupted public order es- pecially after dark. Another positive aspect, which increased visual inspection of the space, was the installation of a security camera system at the main entrance near the bus stop and in the middle of the area.

Another beneficial step is a solution based on planting low vegetation, which provided a regular trimming of treetops - at a minimum of three meters from each individual tree and the surrounding terrain - will not reduce natural surveillance. One certain problem related to this proposal is the addressing of small architectural elements - benches, other type of which could eliminate potential vandalism or drunk
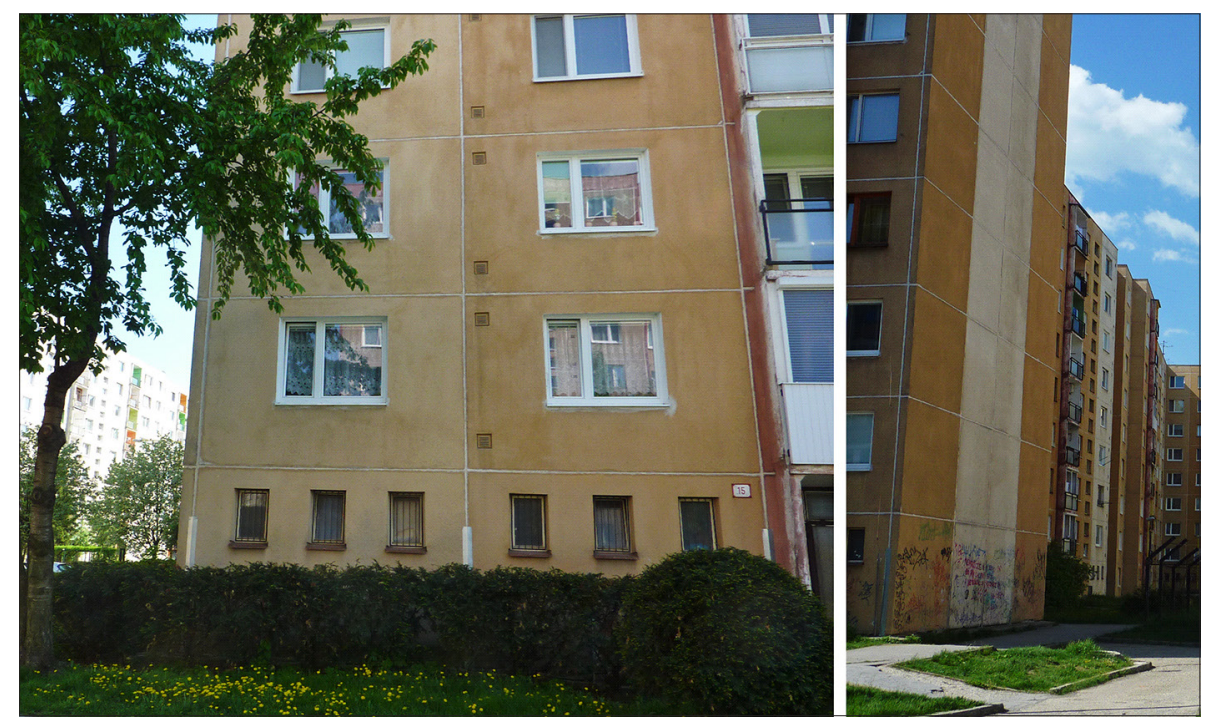

Figure 6. Flat buildings on the Sibírska Street in Prešov: on the left - example with free access to the house that is damaged by graffiti, on the right - house with green bushes barriers that hinder access for graffiti creators (2013)

Foto: K. Matlovičová 
or homeless people sleeping on them. Other changes would require synergy between owners and those leasing shops in the shopping centre. This involves primarily ensuring a two-way view through windows, which would strengthen the effect of natural surveillance (Figure 5).

The above-described revitalization, however, has not brought an improvement in natural access control, since, in this respect, it has been preserved the original conditions. The inner part of the city remains accessible through seven corridors (Figure 4). For now, the possibility of locking, especially in the evening, when the possibilities of natural surveillance are naturally reduced has not been resolved. A possible barrier could be created using lockable entry gates that can control the movement of people in the inner space so that they can be also controlled by a camera security system, e.g. by opening only the main entrance (entrance no. 1 in Figure 4) and the eastern entrance (entrance no. 4 in Figure 4). This would narrow the area for passing into the corridor in the east - west direction, which could be better controlled through the already installed CCTV. Finally, similarly as in the previous case, it would be also beneficial to plant green barriers near walls (e.g. as in Figure 6).

The last rule is territorial reinforcement and maximization of spatial differentiation clarity. In this regard, clear differentiation of public and private space could help, especially in the outer part of the building. Greater transparency could also be achieved by installing orientation maps showing escape routes.

\section{Estate Sekčov}

According to residents of Prešov, the worst environment is in the Sekčov estate. This area is the most densely populated in Prešov (it currently has 24,102 inhabitants, which represents about $1 / 4$ of the city's in- habitants) (Matlovičová, 2011). Compared with the Sídlisko III estate, the Sekčov estate has a greater density of buildings and low vegetation (mainly grassland) is dominant in the areas between blocks of flats. Missing parks with tall green plants are perceived negatively by the inhabitants (Matlovičová, 2011). This situation became the impetus for citizens to build pressure on local authorities to fulfil plans to build a central city park in the nearby surrounding. Due to numerous problems, however, its construction has not started yet.

Individual parts of the estate are different in nature. In view of the above-mentioned principle of natural surveillance, the rectangular formations of residential blocks with relatively large inner spaces between blocks of flats appears to be very suitable for applying the CPTED concept. These spaces primarily serve as a rest area with many playgrounds. The problem is the pedestrian underpasses. These were built in order to increase access to these otherwise closed areas. Dark enclosed spaces represent a risky architectural element in terms of security. A solution could be a camera security system or convex mirrors enabling the monitoring of parking areas in front of blocks of flats (Figure 7).

On this estate, one chain store is also located (Figure 8). The concept used by these stores is a good example of how to ensure the fulfilment of "eyes on the street". Cash registers, usually with the largest concentration of customers, are located next to the glass wall, which enables the monitoring of the situation in the parking area in front of the store (Figure 8)

The high concentration of population, few tall green plants together with monotonous and densely located buildings reduce the so called readability of places and, therefore, also territorial reinforcement is important. In this case, installed orientation maps
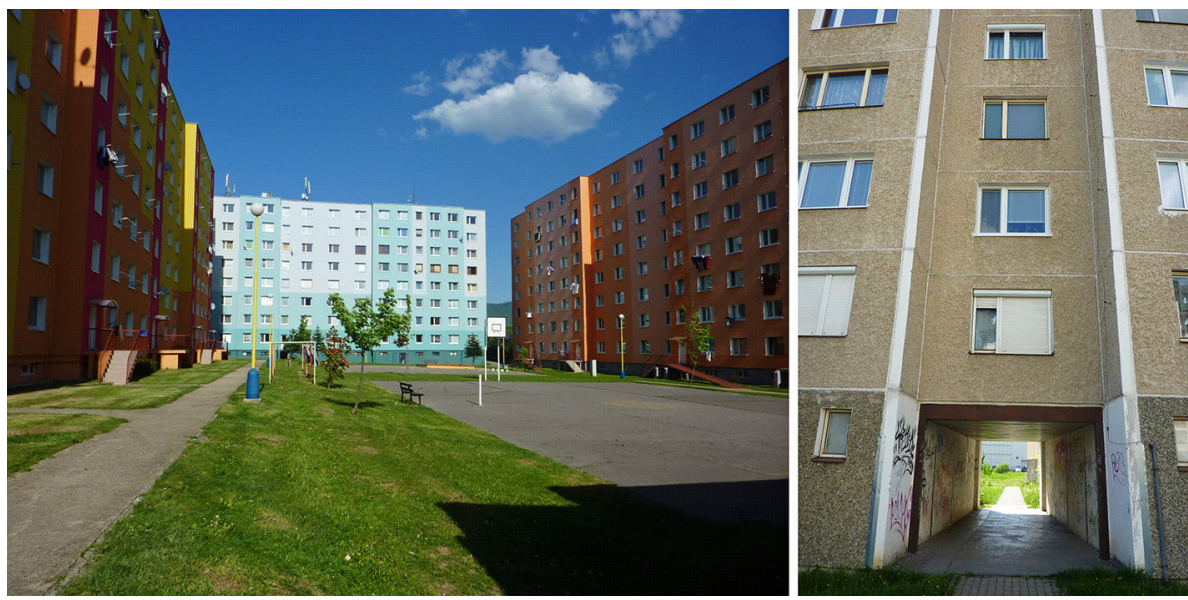

Figure 7. Courtyard between blocks of flats - example of an underpass on the estate Sekčov in Prešov - two examples of public surveillance: sufficient one on the left, inadequate one on the right (2013)

Foto: K. Matlovičová 


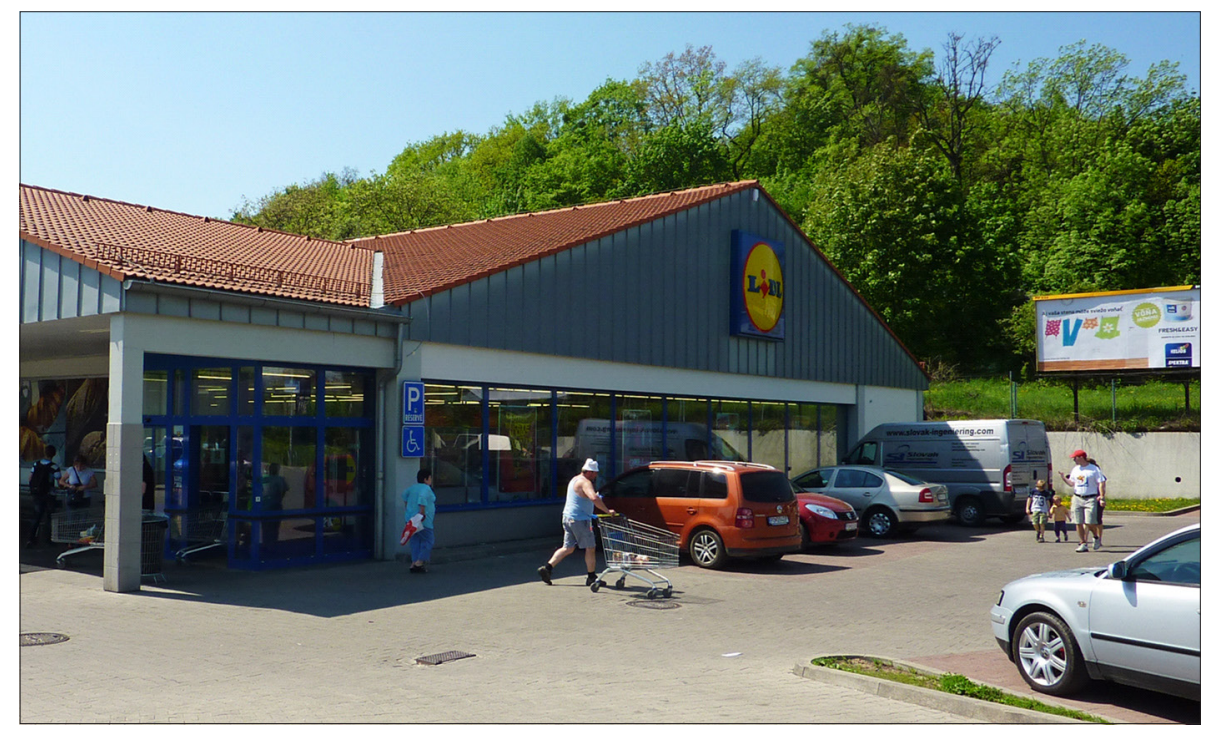

Figure 8. Chain store in Prešov - example of parking area with good public oversight (2013) Foto: K. Matlovičová
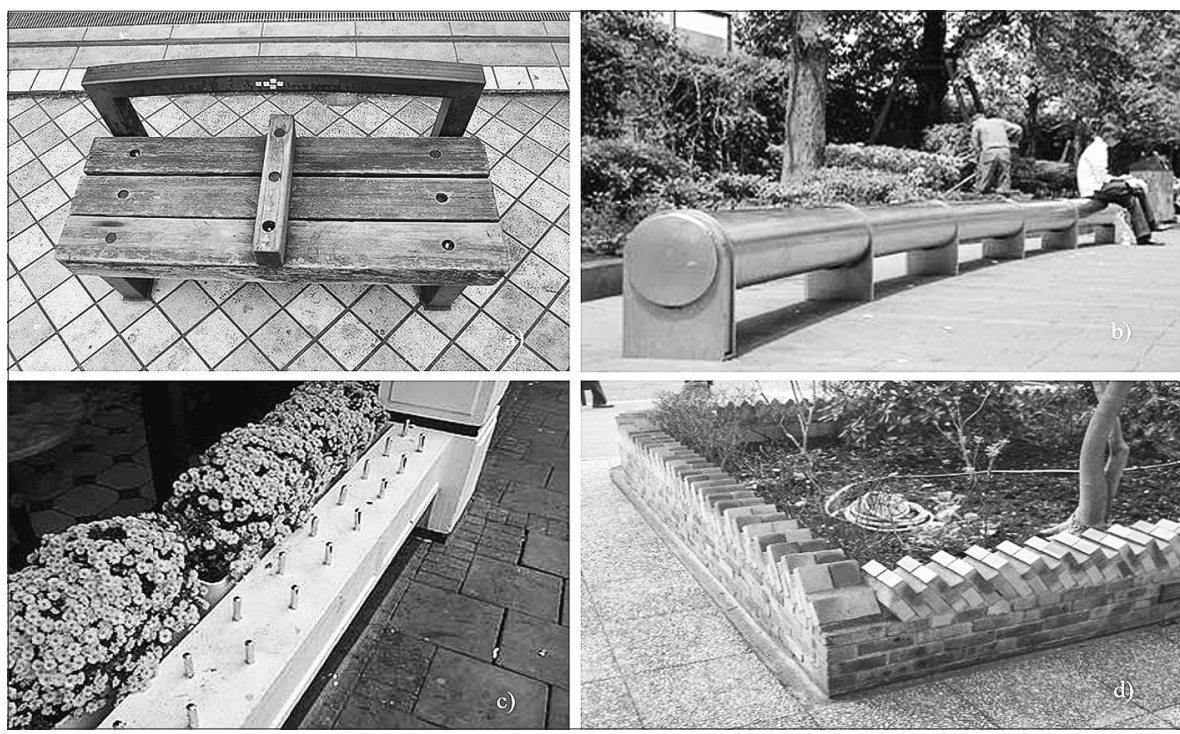

Figure 9. Examples of suitable design of benches and curbs in public places Source: a) Koerner 2009; b) Rubio 2012; c) Lockton 2008; d) Elfort, Schaller 2013

of the surrounding area including 'you are here' locators could help. Higher readability of places is usually achieved through good lighting and simple and well recognisable street signs, which allow easy identification of safe routes to a given destination and at the same time identification of potentially dangerous places and thus, how to avoid them.

\section{Conclusion}

The CPTED concept offers one a possible approach in enhancing the sense of security in the urban environment. However, in Slovakia and other mainly EastCentral European countries, this approach is still rather infrequently used. An important prerequisite is its acceptance already in the process of planning of new buildings or entire urban districts. Its applicability is not excluded even in cases of existing elements in the urban environment. The efficiency and effectiveness of various strategies and CPTED measures can be achieved by careful planning emanating from a rigorous analysis of crime in the area of interest.

Although the issue of crime reduction is one of the permanently discussed agendas of politicians as well as various local organizations, while studying existing available resources, no reference was found to the application of the CPTED concept in Slovak cities. Therefore, it can be assumed that the subject of CPTED will become the subject of further academic interest among Slovak experts not only in the field of ge- 
ography and criminology, but also experts in the field of architecture, psychology, sociology, territorial marketing and other fields and will stimulate discussion among professionals as well. Broader and more intensive interest is actually the only way to more deeply elaborate on the theoretical and methodological postulates of CPTED, which can bring this concept to a qualitatively higher level. Consequently, this concept can generate new useful knowledge how to improve the environment of citizens through the formation and modification of the urban environment.

\section{Acknowledgements}

The article is part of the grant project KEGA č. o46PU4/2015 (2015-2017).

\section{References}

Elfort A., Schaller G. 2013. Les Anti-sites - Archivage d'excroissances urbaines anti-SDF. Archive of anti-SDF urban outgrowths, excroissance urbaine anti-SDF, [online]. Dostupné na: http://www.flickr. com/photos/7211263@No2/sets/72157602377494963/, citované: $20.5 \cdot 2013$

City Of Orlando 2007. Crime Prevention Through Environmental Design. [online]. 2007, [2012-01-26]. Available at: http://khup.com/download/4_keyword-crime-prevention-through-environmentaldesign-crowe/crime-prevention-through-environmental-design.pdf

Clarke, V.R. 2002. The theory of crime prevention through environmental design. [online]. 2002, [2012-01-14]. Available at: http://www3.cutr.usf.edu/ security/documents $\%{ }_{5}$ CCPTED\% $\%$ CTheory\%2o of\%2oCPTED.pdf

Crowe, T. 2000. Crime Prevention through Environmental Design: Applications of Architectural Design and Space Management Concepts. Florida: National Crime Prevention Institute, pp. 320.

Crowe, T., Zahm D.L. 1994. Crime Prevention through Environmental Design. In Land Development. [online]. 1994. [2012-01-25], s. 22-27. Available at: http:// www.popcenter.org/Responses/closing_streets/ PDFs/Crowe_Zahm_1994.pdf

Dale, L. 2011. Crime Map of the Slovak Republic. Where is a situation the worst? [online]. 2011, [2012o1-26]. Available at: http://tvnoviny.sk/sekcia/spravy/krimi-a-nehody/na-slovensku-nenajdete-anijedine-miesto-kde-by-zlocin-neprekvital.html. (in Slovak)

Henrico Police 2011. Crime Prevention Through Environmental Design. [online]. 2011, [2012-01-26]. Available at: http://www.co.henrico.va.us/police/ pdfs/cpted_checklist.pdf
Jacobs, J. 1961. The Death and Life of Great American Cities. New York: Random House, pp. 458.

Jacobsová, J. 1975. Death and Life of American cities. Prague: Odeon, 1961. pp. 288

Jeffery, C. R. 1971. Crime Prevention through Environmental Design. Beverly Hills, CA: Sage Publications, 290 pp.

Keppl, J, Benkovičová, L. 2011. Architectural tool for building a safe urban environment. In Urbanita [online]. 2011, volume 23, no. 2, [2012-01-25], pp. 22 - 27 Available at: <http://www.urbion.sk/wpcontent/uploads/2011/o1/Urbanita_2011_02_web3. pdf $>$ ISSN 0139-5912.

Koerner, I.B. 2009. We Don't Serve Your Kind Round Here.. 2009, [online], [13.1.2012], dostupné na internete: http://www.microkhan.com/2009/02/20/wedont-serve-your-kind-round-here/

KRPZ, 2012. Regional Directorate of the Police Force of SR Prešov, official statistics (in Slovak).

Lockton D. 2008. On 'Design and Behaviour' this week: Do you own your stuff? And a strange council-run 'Virtual World for young people', [online]. 2008, dostupné na: http://architectures.danlockton. co.uk/2008/12/14/on-design-and-behaviour-thisweek-do-you-own-your-stuff-and-a-strange-council-run-virtual-world-for-young-people/\#more

Lukić A. 2002. The social functions of commercial and business center: example of Kaptol Centre in Zagreb. Croatian Geographical Bulletin, Vol.64. No.1. June 2002, pp. 73 - 91

Lukić A., Jakovčić M. 2004. Location and function of hypermarkets and shopping centres in Zagreb. Dela 22, pp. 39-54.

Madliak, J. et. al. 2005. Criminology. 1.vol. Košice: UPJŠ in Košice, 2005. pp. 360. ISBN 80-7097-601-2.

Matlovičová, K. 2011. The analysis of urban environment perception - a basis of marketing strategy oriented to residents. Case study of the city of Prešov. In: Ježek, J., Kaňka, L. (eds.): Competitiveness and Sustainable Development of Small Cities and Rural Regions in the Czech Republic. Plzeň: ZČU, pp. 169 - 196 (in Slovak)

Matlovičová, K. 2014. Theoretical Framework of the Intra-Urban Criminality Research: Main Approaches in the Criminological Thought. Acta facultatis studiorum humanitatis et naturae Universitas Prešoviensis, Natural Sciences, Folia Geographica, 56, 2, pp. 29 - 40. (in Slovak)

Matlovičová, K., Mocák, P.2014. Intra-Urban Criminality and its prevention within the conceptual framework of the CPTED (Example of the city of Prešov). Geographical Journal, 66, 3, pp. 199 - 223.

Matlovičová K., Mocák P., Andrejko J. 2012. Objective and subjective dimensions of the criminality in the city of Prešov. Acta Facultatis Studiorum Humani- 
tatis et Naturae Universitatis Prešoviensis, Natural sciences, Folia Geographica 20, Vol. LIV., No. 20, PU Prešov, pp. 146-172. (in Slovak)

Mocák, P. 2012. The analysis of potential impacts of urban environmental elements on the crime in Presov. Master's thesis, University of Prešov, 124 p. (in Slovak)

Newman, O.1972. Defensible Space. Crime Prevention Through Urban Design. New York: Macmillan, 1972. 264 pp. ISBN 978-0020007500.

Michálek, A., 2008. Dynamics of crime and drug addiction development in the districts of Slovakia. Slovak Statistics and Demography , 18, 1, pp. 86 107. (in Slovak)

Oficial website of the city of Prešov: Oficial Document by Department of the Chief Architect and Urban Planning. 2013. Available at: http://www.Prešov.sk/ portal $/ ? \mathrm{c}=12$ \&id $=12597$

Olsson, K., Berglund, E. 2009. City Marketing The Role of the Citizens. In: Nyseth, T., Viken, A. (eds.). Place Reinvention: Northern Perspectives, Farnham: Ashgate, pp. 127 - 143. (in Slovak)

Ondrejkovič 1995. The new orientation of criminology and labeling approach. Bratislava: Faculty of Education, Comenius University in Bratislava, 1995. pp.76.

Pauls, T., Zywna, D., Prochilo, K., White, S., Christie, F., Hainer, C. 200o. Crime Prevention Through Environmental Design. [online]. Virginia Beach [cit. 2012-01-26]. Available at: http://www.humanics-es. com/cpted.pdf

Polišenská, A. 2010. Burglary offenses: Theory and research abroad. In Security magazine. ISSN 12108723, 2010, vol. 17, no. 5 pp. 54-58.

Prince William County 2011. Crime Prevention Through Environmental Design. A Guide to safe environments in Prince William County, Virgin- ia. [online]. 2011, [2012-02-23]. Available at: http:// www.alexecon.org/files/PWCPTEDStrategies.pdf

Remy, M. 200o. Oscar Newman's Theory of Defensible Space. [online]. 2000, [2012-01-25]. Available at: http://criminology.fsu.edu/crimtheory/newman. htm

Rubio F.D. 2012. Benches, stairs, sidewalks and the politics of urban comfort, [online], dostupné na: http://www.materialworldblog.com/2011/11/benches-stairs-sidewalks-and-the-politics-of-urbancomfort/, [1.4.2013]

Robinson, M.B. 1996. The Theoretical development of CPTED: 25 years of responses to C. Ray Jeffrey.[online]. 1996. [2012-01-25]. Available at: <http://www. pscj.appstate.edu/vitacpted 2.html>

Romelić J., Plavša J., Stojanović V., Lazić L. 2007. Geographical Basis for the Distribution and Organisation of Industry in Bačka, Geographica Pannonica, Vol. 11 (2007), pp. 43-47.

Schmeidler, K., 2000. The City Environment, Urban Production and Social Pathology, 2000, 33, 4, pp. 316 - 325. (in Czech)

Sorensen, S., Hayes, J., Randy, A. 2008. Understanding CPTED and Situational Crime Prevention. In 21st Century Security and CPTED. Florida: CRC Press, 2008. pp. 53 - 78. ISBN 978-1420068078.

The City Police in Prešov (2007-2013). The City Police in Prešov informative report about activities from 2007 - 2013, ms. (in Slovak)

VÚZH, 2001. File „katastez.blk“ (TOPOL Software Formats). Bratislava: Research Institute of Irrigation Management of the Slovak Republic, ms. (in Slovak)

Wood, E. 1961. Housing Design A Social Theory. New York: Citizens' Housing and Planning Counsel of New York, 1961, 31 pp. 